\title{
Penentuan Mut'ah Wanita Karir dalam Pandangan Hukum Positif Indonesia
}

\author{
Sanuri Majana \\ Institut Agama Islam Negeri (IAIN) Bengkulu \\ sanurimajana@gmail.com
}

\begin{abstract}
The purpose of this research is to know how to give mut'ab if the divorced woman is a career women; Whether the establishment is the same with ordinary women who are not career women. This research is a library research in which the secondary data were obtained from interviews using literature literature such as the Qur'an and hadith. Research begins by way of describing the description of the problems of the data obtained, then drawn conclusions with inductive techniques.In this article, it can be concluded the determination of mut'ahtalak for career women, that is first, the determination of mut'abtalak for career woman in positive law view in Indonesia is based on propriety contained in article $160 \mathrm{KHI}$ and applies not only to career woman. Sufficiency is worthy or not the amount for the wife in terms of husband's economic ability. Second, the determination of mut'ah for career woman based on propriety and ability of husband as in article $160 \mathrm{KHI}$. According to the jurisprudence of the judge,the propriety is reasonable whether or not the number is seen from the aspect of the husband's economic capability as well as the aspect of his wife, and also there are the customs prevailing in the environment of the relevant parties in accordance with surah al-Baqarah verse 236.
\end{abstract}

Keywords: Mut'ah, career woman, husband ability

\begin{abstract}
Abstrak
Tujuan penelitiaan ini adalah untuk mengetahui bagaimana pemberian mut'ah apabila kondisi wanita yang diceraikan berstatus sebagai wanita karir. Apakah sama atau tidak penetapannya dengan wanita biasa yang bukan wanita karir. Penelitian ini adalah penelitian kepustakaan atau library research. Di mana dalam mengkaji data sekunder yang didapat dari wawancara dengan menggunakan literature kepustakaan seperti Alquran dan hadits. Penelitian dimulai dengan cara mendekripsikan gambaran tentang permasalahan dari data yang didapat kemudian ditarik kesimpulannya dengan teknik induktif. Dalam artikel ini dapat disimpulkan penetapan mut'ah talak bagi wanita karir, yaitu pertama, penetapan mut'ah talakbagi wanita karir dalam pandangan hukum positif di Indonesia adalah berdasarkan kepatutan yang terdapat pada pasal 160
\end{abstract}

Al Istinbath : Jurnal Hukum Islam vol. 3, no. 1, 2018

STAIN Curup-Bengkulu | p-issn: 2548-3374; e-issn: 2548-3382

Available online at : http://journal.staincurup.ac.id/index.php/alistinbath 
KHI dan berlaku umum bukan hanya pada wanita karir. Kepatutan adalah layak atau tidaknya jumlah tersebut untuk istri dilihat dari segi kemampuan ekonomi suami. Kedua, penetapan mut'ab bagi wanita karir berdasarkan kepatutan dan kemampuan suami seperti dalam pasal 160 KHI.Menurut yurisprudensi hakim kepatutan adalah layak atau tidaknya jumlah tersebut dilihat dari segi kemampuan ekonomi suami serta patut atau pantas juga dilihat dari segi istri, dan juga adat istiadat yang berlaku di lingkungan pihak-pihak yang terkait yang sesuai dengan surah al-Baqarah ayat 236.

Kata Kunci: Mut'ah, wanita karir, kemampuan suami

\section{Pendahuluan}

Kebahagiaan dalam keluarga merupakan keinginan yang diharapkan semua manusia, dan semua itu akan terasa disaat sebuah keluarga menjalankan apa yang menjadi kewajiban dan hak masing-masing baik suami ataupun istri dalam sebuah keluarga. Oleh karena itu, segala tingkah laku, gerak langkah, selalu berorientasi kearah itu walaupun dalam aplikasi memakai cara yang berlawanan dengan tujuan tadi.

Namun pada kenyataannya tidak semua keluarga mendapat ketenangan dalam kehidupan rumah tangga mereka, ada keluarga yang tidak tenang dan menyenangkan, ada kalanya kehidupannya begitu ruwet dan memusingkan.Hal tersebut terjadi karena peran dan fungsi mereka khususnya bagi suami ataupun istri sudah tidak dilaksanakan. Hingga terjadi suatu hal yang halal tapi dibenci Allah yaitu perceraian. Perceraian itu bisa saja berupa cerai gugat dari pihak istri maupun cerai talak dari pihak suami.

Berbicara mengenai cerai talak, salah satu efeknya adalah berupa adanya mut'ah yang harus diberikan seorang suami kepada istrinya. Hal ini diatur oleh Kompilasi Hukum Islam dalam pasal 158, 159, 160 tentang: Mut'ab wajib diberikan oleh bekas suami dengan syarat tertentu, Mut'ah sunnat diberikan oleh bekas suami tanpa syarat tersebut pada pasal 158, besarnya Mut'ah disesuaikan dengan kepatutan dan kemampuan suami ${ }^{1}$. Mengenai hal mut'ab ini ada berbagai pendapat para fuqaha, baik itu yang mengatakan mut'ah itu wajib ataupun sunnah. Namun yang menarik menurut penyusun adalah mengenai penafsiran kata kepatutan dalam Kompilasi Hukum Islam maupun surah al-Baqarah ayat 236 tersebut.

"Orang yang mampu menurut kemampuannya dan orang yang miskin menurut kemampuannya (pula), yaitu pemberian menurut yang patut".

1 Tim Redaksi Pustaka Yustisia, Hukum Keluarga (Kumpulan Perundangan Tentang Kependudukan, Kompilasi Hukum Islam, Perkawinan, Perceraian, KDRT dan Anak), (Yogayakarta: Pustaka Yustisia. 2010), Cetakan pertama, h. 265. 
Dengan pernyataan seperti ini, maka ada tiga unsur kepatutan yang mesti diperhatikan dalam pemberian mut'ah. Pertama, kepatutan atau kepantasan berdasarkan kemampuan suami, dan itu didasarkan pada ayat di atas. Artinya, suami yang kaya tidak pantas memberikan mut'ah yang sama jumlahnya dengan suami yang termasuk golongan miskin, dan sebaliknya. Kedua, patut atau pantas bagi istri. Artinya, istri yang terbiasa dengan pola hidup cukup apalagi mewah dengan suami itu atau keluarganya sebelumnya, tidak pantas kalau mendapat mut'ah yang jumlahnya sedikit. ${ }^{2}$ Seperti yang dikatakan al-Kasaniy yang dikutip oleh Najib Chicharito dalam makalahnya yang berjudul Mut'ah Pasca Cerai, karena mut'ah itu sendiri adalah sebagai ganti dari kemaluannya. Oleh karena itu, keadaan isteri lah yang jadi pedoman dalam penentuan mut'ab itu. Ketiga, patut atau pantas menurut adat yang berlaku di lingkungan tempat mereka hidup. Hal ini perlu mendapatkan perhatian, setidaknya untuk menghindari terjadinya kesenjangan sosial antara istri yang diberi mut'ah dengan orang-orang yang berada di sekitarnya.

Dari ketiga penafsiran itu ada hal yang menarik penyusun untuk meneliti bagaimana jika seandainya posisi istri yang menerima mut'ab adalah seorang wanita karir. Yang mungkin saja pengahsilannya tidak jauh berbeda dari suami, bahkan mungkin lebih. Karena syarat kepatutan tadi bukan hanya dari sisi suami melainkan dari istri juga.Persoalan tersebut juga dikarenakan pada zaman sekarang ini lumrah terjadi. Dan perkara tersebut juga mungkin sudah sering didapati dan ditemui dalam perkara yang ditangani atau diselesaikan oleh Pengadilan Agama. Namun secara teori maupun penjelasan ukuran dan penetapan yang kerap digunakan oleh para hakim di Pengadilan Agama juga sangat menentukan dan sangat menarik untuk dibahas.

\section{Pembahasan}

\section{Pengertian Mut'ah dan Dasar Hukum Mut'ah}

Dalam istilah agama talak artinya melepaskan ikatan perkawinan atau bubarnya hubungan perkawinan ${ }^{3}$. Syariat Islam memberikan kepada laki-laki hak untuk mengakhiri kehidupan rumah tangganya dengan talak ${ }^{4}$. Setelah menjatuhkan talak, seorang bekas suami harus menunaikan beberapa tanggungan dan kewajiban beserta segala akibatnya sesuai aturan syara'. Akibat dari penjatuhan talak tersebut adalah sebagai berikut:

${ }^{2}$ Chicharito, Najib. Mut'ab Pasca Cerai.(Google:najib@gmail.com. 2012), h. 4.

${ }^{3}$ Sayyid Sabiq, Fiqh Sunnah, terj. Muhammad Thalib, (Bandung: Al- Ma'arif, 2010), Jilid 8, Cet. ke-20, h. 7.

${ }^{4}$ Yusuf Al-Qaradhawi, Fatwa-Fatwa Kontemporer, terj. As'ad Yasin, (Jakarta: Gema Insani, 2009), Cet. ke-6, h. 507. 
1. Harus melunasi mahar yang belum dibayar atau yang belum lunas. Mahar (maskawin) ialah suatu pemberian wajib dari calon suami kepada calon istrinya baik dalam bentuk benda maupun jasa ${ }^{5}$.

2. Memberi nafkah wajib selama masa iddah

3. Memberi upah penyusuan anak dan nafkah mereka hingga dewasa.

4. Memberi mut'ah talak kepada bekas istri.

Kata mut'ah dengan dhammah mim (mut'ah) atau kasrah (mit'ah) akar kata dari al-mata', yaitu sesuatu yang disenangi ${ }^{6}$. Mut'ah (المتعة) secara bahasa artinya adalah kesenangan ${ }^{7}$. Sedangkan menurut istilah yaitu sesuatu yang diberikan kepada istri yang dicerai sebagai penghibur ${ }^{8}$. Maksudnya materi yang diserahkan suami kepada istri yang dipisahkan dari kehidupannya karena talak atau semakna dengannya dengan syarat tertentu.

Secara definitive, makna mut'ab adalah sejumlah harta yang wajib diserahkan suami kepada istri yang telah diceraikannya dengan cara cerai talak atau cara yang semakna dengan hal tersebut. Dengan kata lain apabila terjadi perceraian yang bukan melalui cara cerai talak misalnya dengan cara kbuluk (cerai gugat) yang perceraian tersebut berasal dari pihak istri maka istri tidak mempunyai hak mut'ab sama sekali.'

Mengenai mut'ah terdapat beberapa ayat yang menjadi dasar hukumnya, walaupun ada perbedaan pandangan diantara para ulama, namun hal tersebut akan dibahas setelah pembahasan tentang dasar hukum mut'ab ini. Yang pertama adalah firman Allah SWT dalam surah al-Baqarah ayat 236 yang berbunyi sebagai berikut:

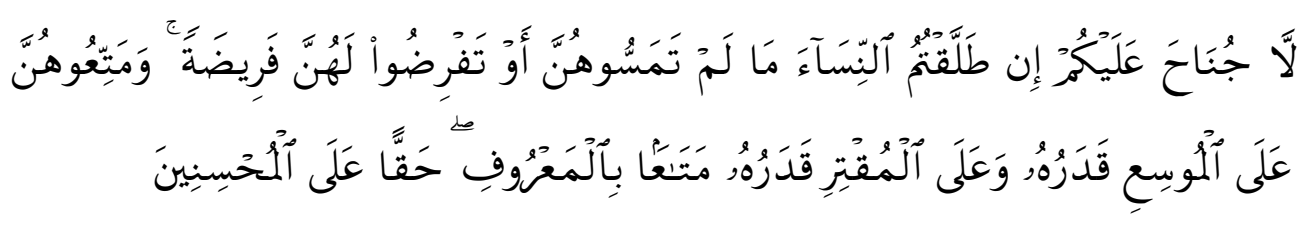

${ }^{5}$ H. M. A. Tihami dan Sohari Sahrani, Fikih Munakahat, (Jakarta: Rajawali Pers, 2010), Cet. ke-2, h. 37.

${ }^{6}$ Abdul Aziz Muhammad Azzam dan Abdul Wahhab Sayyed Hawwas, Fiqh Munakahat, (Jakarta: Amzah, 2011), cet. ke-2, h. 207.

7 Ahmad Dzulfikar, Kamus Ekstra Lengkap Arab-Indonesia-Inggris, Jakarta: Mutiara Media, 2010), Cet. Pertama, h. 503.

${ }^{8}$ Hasbi Ash- Shiddieqy, Tafsir Al-Bayan, (Bandung: Al-Ma'arif, 1966), Jilid 1, h. 259.

${ }^{9}$ Husni Syams ,Hak. Mut'ab Istri Pasca Perceraian(fikihonline.blogspot.com :Ensiklopedi

Fikih Online, 31 Maret 2010), h. 5. 
Tidak ada kewajïban membayar (mahar) atas kamu, jika kamu menceraikan isteri-isteri kamu sebelum kamu bercampur dengan mereka dan sebelum kamu menentukan maharnya.dan hendaklah kamu berikan suatu mut'ab (pemberian) kepada mereka. Orang yang mampu menurut kemampuannya dan orang yang miskin menurut kemampuannya (pula), yaitu pemberian menurut yang patut.Yang demikian itu merupakan ketentuan bagi orang-orang yang berbuat kebajikan. ${ }^{10}$

Sedangkan ayat yang kedua dalam surah al-Baqarah ayat 241 yang berbunyi sebagai berikut:

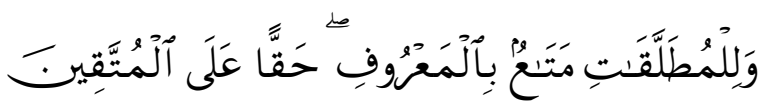

Kepada wanita-wanita yang diceraikean (hendaklah diberikan oleh suaminya) mut'ah menurut yang ma'ruf, sebagai suatu kewajiban bagi orang-orang yang bertakwa. ${ }^{11}$

Ayat diatas bermakna bahwa tiap-tiap perempuan yang diceraikan berhak menerima mut'ah dari bekas suaminya dengan cara yang baik.

Suami yang memberikan hiburan tersebut adalah orang yang bertaqwa kepada Allah oleh karenanya ia menjadi pemurah memberikan bantuan kepada bekas istrinya dengan ketulusan hati sejalan dengan petunjuk agama yaitu mengambil istri dengan baik atau menceraikan dengan baik. ${ }^{12}$

Dan ayat yang ketiga terdapat dalam surah al-Azhab ayat 28 yang berbunyi sebagai berikut:

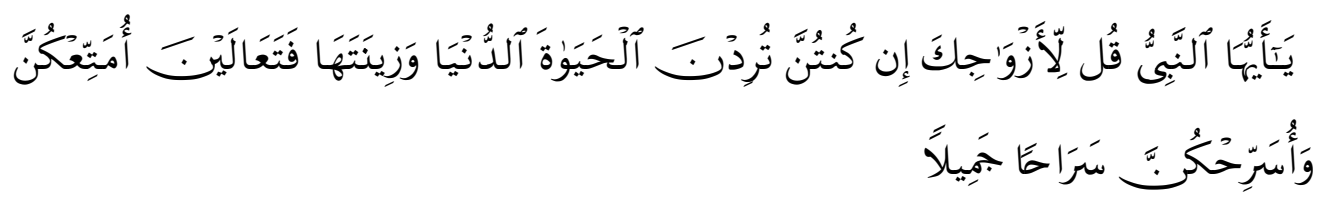

Hai Nabi, Katakanlah kepada isteri-isterimu: "Jika kamu sekalian mengingini kehidupan dunia dan perbiasannya, maka marilah supaya kuberikan kepadamu mut'ah dan aku ceraikean kamu dengan cara yang baik."

Mut'ah wajib diberikan kepada setiap wanita yang dicerai sebelum bercampur dan sebelum kepastian mahar, yang merupakan pendapat ulama Hanafiyah dan As-Syafi'i dalam pendapatnya yang baru (qaul jadid). ${ }^{14}$ Pendapat

\footnotetext{
${ }^{10}$ Departemen Agama, Al-Quran dan Terjemahnya, (Bandung: Diponegoro. 2006 ), h. 30.

${ }^{11}$ Hasbi Ash- Shiddieqy, Op. Cit. , h. 260-261.

${ }^{12}$ Sonhadji dan Zaini Dahlan, Alquran dan Tafsirnya, (Yogyakarta: Dana Bhakti Wakaf,

${ }^{13}$ Departemen Agama, Op. Cit. h. 336.

14 Aziz Muhammad, Op. Cit. h. 207.
} 1990), Jilid 1, h. 405. 
tersebut dikutip oleh Abdul Aziz Muhammad dalam bukunya yang berjudul Fiqh Munakahat.

Firman Allah dalam surah al-Baqarah ayat 236, yang berarti "atau kamu menentukan maharnya", maksudnya belum ditentukan oleh yang bersangkutan.Maknanya selama belum kamu sentuh dan belum kamu tentukan maharnya. Diantara dalil yang menunjukkan makna tersebut dalam firman Allah setelahnya tentang hukum wanita yang dicerai sebelum bercampur dan ditentukan maharnya, yaitu pada ayat berikutnya yang berbunyi sebagai berikut:

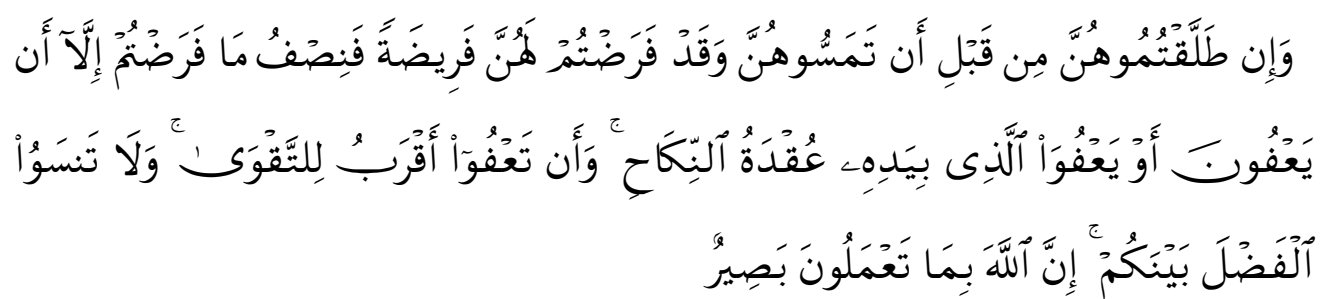

Jika kamu menceraikan isteri-isterimu sebelum kamu bercampur dengan mereka, padahal sesunggubnya kamu sudah menentukan maharmya, maka bayarlah seperdua dari mahar yang telah kamu tentukan itu, kecuali jika isteri-isterimu itu mema'afkan atau dima'afkan oleh orang yang memegang ikatan nikah, dan pema'afan kamu itu lebih dekat kepada takwa. dan janganlah kamu melupakan keutamaan di antara kamu. Sesunggubnya Allah Maha melibat segala apa yang kamu kerjakan. (QS. al-Baqarah: 237) ${ }^{15}$

Ayat pertama menjelaskan hukum wanita yang dicerai sebelum bercampur dan belum ditentukan maharnya, ia wajib diberi mut'ah. Ayat kedua menjelaskan hukum wanita yang cerai sebelum bercampur dan telah ditentukan maharnya, hukumnya adalah ia wajib diberi separuh mahar yang ditentukan.

\section{Pendapat Para Ulama Mengenai Hukum Mut'ah}

1. Mut'ah hukumnya wajib menurut sebagian imam dari kalangan sahabat Tabi'in, seperti Ali bin Abi Thalib, Ibrahim an-Nakha'i, Ibnu Syihab azZuhri, Abu Qilabah, Al-Hasan, dan Sa'id bin Jubair sebagaimana yang dikutip oleh Yusuf Qaradhawi dalam bukunya fatwa-fatwa kontemporer halaman 507. ${ }^{16}$ Mereka mengatakan bahwa tiap-tiap wanita yang ditalak berhak mendapatkan mut'ah. Alasan mereka adalah keumuman firman Allah surah al-Baqarah ayat 241:

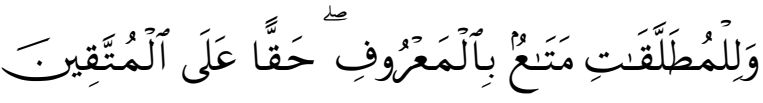

\footnotetext{
${ }^{15}$ Departemen Agama, Op. Cit.,h. 30.

16 Yusuf Al-Qaradhawi, Loc. Cit.
} 
Kepada wanita-wanita yang diceraikan (hendaklah diberikan oleh suaminya) mut'ab menurut yang ma'ruf, sebagai suatu kewajiban bagi orang-orang yang bertakwa. ${ }^{17}$

Alquran tidak memberikan batasan tentang mut'ah ini, tetapi hanya menetapkan menurut yang ma'ruf.Batasan yang ma'ruf disinilah yang dianggap layak oleh fitrah yang sehat, diakui oleh urf yang matang, serta diridhai oleh ahli ilmu dan agama.

2. Penggalan surah al-Baqarah ayat 236 yang berarti 'dan berilah mut'ah kepada mereka' adalah suatu perintah. ${ }^{18}$ Perintah secara hakikat berlaku untuk kewajiban selama tidak ada tanda-tanda yang qarinah (menyertainya) yang memalingkan kewajiban tersebut kepada makna lain, yakni sunnah atau anjuran dan lainnya. Ketika tidak didapatkan qarinah, perintah di sini kembali kepada hakikatnya, yaitu wajib. ${ }^{19}$ Jadi, mut'ab wajib bagi wanita yang dicerai sebelum dicampuri dan belum dipastikan maharnya.

Pendapat pertama mengenai mut'ah hukumnya wajib berdasarkan alasan berikut:

Kata "ala"yang berarti atas pada surat al-Baqarah ayat 236 di atas bermakna kewajiban dan kata "haqqan"yang berarti pasti memperkuat kewajiban dari sisi lafal lain, karena hakikatnya menuntut kewajiban. Berdasarkan uraian di atas, penggabungan kata ala dan haqqan menuntut penguatan atas hukum wajib.

Kewajiban mut'ah dalam kondisi ini sebagai pengganti kewajiban, yaitu separuh mahar mitsil. Pengganti wajib hukumnya juga wajib, karena ia menempati di tempat wajib dan memposisikan pada posisinya.

Mahar mitsil yaitu mahar yang seharusnya diberikan kepada perempuan atau diterima oleh perempuan, sama dengan perempuan lain, umurnya, kecantikannya, hartanya, akalnya, agamanya, kegadisannya, kejandaannya dan negerinya sama ketika aqad nikah dilangsungkan. ${ }^{20}$

Selain kedua hal diatas yang mendukung diwajibkan mut'ah, dasar hukumnyapun juga menjadi alasan yaitu talak ini jatuh pada saat nikah sedangkan menikah menuntut pengganti iwadh (ganti rugi) yang didapatkan wanita.Dalam kondisi talak terjadi sebelum bercampur disebutkan maharnya separuh dari yang disebutkan, sementara mahar yang tidak disebutkan maka penggantinya adalah mut'ah,sehingga pernikahan ini tidak lepas dari iwadh bagi wanita.

${ }^{17}$ Hasbi Ash- Shiddieqy, Loc. Cit.

18 Aziz Muhammad, Op. Cit. ,h. 209.

${ }^{19}$ Ibid. ,h. 209.

${ }^{20}$ Sayyid Sabiq, Fiqh Sunnah, terj. Muhammad Thalib, (Bandung: Al- Ma'arif, 2010), Jilid 7, Cet. ke-20, h. 69. 
Pendapat yang kedua juga dikutip oleh Aziz yaitu tentang mut'ah hukumnya sunnah. Sebagian ulama berpendapat bahwa mut'ah dalam kondisi tersebut tidak wajib, ia hanya sunnah, demikian pendapat Malik, Al-Laits, Ibnu Abi Layla, dan Imam Asy-Syafi'i dalam pendapat yang lama (qaul qadim). ${ }^{21}$

Dengan mengambil dalil firman Allah surah al-Baqarah ayat 236 dan ayat 241, dengan metode pemahaman dua ayat diatas tersebut, sebagai berikut:

1. Kewajiban tidak hanya dikhususkan pada orang-orang yang berbuat baik dan takwa, tetapi juga kepada yang lain. Ketika mut'ah dikhususkan kepada mereka, menunjukkan bahwa mut'ah hukumnya tidak wajib,

2. Kekhususan mut'ah kepada orang-orang yang berbuat baik dan takwa didasarkan pada kebaikan (ihsan) dan anugerah, kebaikan tidak wajib. ${ }^{22}$

Dalil yang dijadikan dasar bagi pendapat kedua terjawab bahwa kewajiban terhadap orang yang berbuat baik dan takwa tidak menghilangkan kewajiban terhadap orang lain. Perbandingannya dengan firman Allah yang berbunyi:

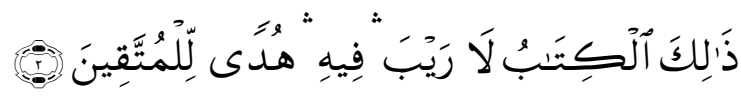

Kitab (al-Quran) ini tidak ada keraguan padanya; petunjuk bagi mereka yang bertaqwa.(al-Baqarah: 2). ${ }^{23}$

Ayat tersebut tidak meniadakan bahwa Alquran juga menunjukkan kepada manusia seluruhnya, baik takwa, orang yang berbuat baik, dan yang lainnya.Pendapat yang kuat berdasarkan penjabaran diatas adalah pendapat yang pertama karena kuat dalilnya dan selamat dari kontradiksi.

1. Wanita yang tidak meminta maharnya tertentu, diserahkan kepada suami atau pertimbangan wali, dan tidak disebutkan besarnya dalam akad (mufawnidhah), apabila ditalak sebelum ditentukan maharnya, tidak diberikan mahar kepadanya, melainkan hanya diberi pemberian untuk menyenangkannya karena telah ditalak (mut'ah). Demikian menurut pendapat Hanafi, Syafi'i, dan pendapat Hambali, yang paling sahih yang dikutip oleh Syaikh al-Allamah yang diterjemahkan oleh Abdullah Zaki Alkaf. dalam bukunya yang berjudul Rahmah al-Ummah fi Ikbtilaf al-

${ }^{21}$ Aziz Muhammad, Op. Cit. ,h. 208.

${ }^{22}$ Ibid. ,h. 210.

${ }^{23}$ Departemen Agama, Op. Cit. h. 2. 
A'immah. Sedangkan menurut pendapat Hambalidalam riwayat lain, Perempuan tersebut berhak mendapat separuhnya dari mahar mitsl. ${ }^{24}$

2. Syafi'iberpendapat sebagaimana yang dikutip Muhammad Jawad Mughniyah, dalam bukunya yang berjudul Fiqh Lima Marhab bahwa Mut'ah adalah kewajiban atas suami untuk istrinya setelah ditalak sebelum dicampuri, tetapi perempuan itu tidak berhak memperoleh suatu mahar. ${ }^{25}$ Karena mut'ah pada prinsipnya sebagai pengganti dari mahar.

\section{Fuqaha'berbeda pendapat tentang ukuran besar kecilnya mut'ah}

Sebagaimana pula mereka berbeda pendapat mengenai kondisi pertimbangan mut'ah, apakah pertimbangan suami saja, atau istri saja atau mungkin pertimbangan keduanya.

1. Abdul Aziz dan Abdul Wahab mengutip dalam bukunya Fikib Munakahat mengenai, ulama Hanafiyah dan Zhahiriyah berpendapat bahwa mut'ah mempunyai ukuran yang ditentukan, yaitu tiga helai pakaian, baju kurung, kerudung, dan rangkapan. Ukuran ini diriwayatkan dari Al-Hasan, Sa’id bin Al-Musayyab, Atha', dan Asy-Sya'bi. ${ }^{26}$

2. Ulama Syafi'iyah berpendapat bahwa mut'ah tidak memiliki ukuran tertentu, tetapi disunnahkan tidak kurang dari 30 dirham atau seharga itu. ${ }^{27}$ Kewajibannya tidak melebihi dari mahar mitsl dan sunnahnya tidak melebihi dari separuh mahar mitsl.Mereka mengambil dalil dari hadis yang diriwayatkan dari Abi Majlaz berkata: "Aku berkata pada Ibnu Umar: 'Beritakan kepadaku tentang mut'ah, 'ia pun memberitakan kepadaku tentang ukuran mut'ah dan aku orang yang dimudahkan. Ia berkata: 'Berikan pakaian begini, berikan pakaian begini, dan berikan pakaian begini, 'Abi Majlaz berkata: 'Cukuplah, aku dapati kira-kira seharga 30 dirham. 'Beliau berkata: 'Perkiraan 30 dirham.' ",28

3. Ulama Hanabillah berpendapat sebagaimana yang dikutip oleh Syaikh alAllamah Muhammad bin Abdurrahman ad-Dimasyki yang berjudul Fiqh Empat Maz̧bab, bahwa mut'ah yang paling tinggi diberi pembantu, yang pertengahan diberi pakaian, dan yang paling rendah diberi pakaian yang cukup untuk shalat, yaitu baju kurung dan kerudung. ${ }^{29}$

${ }^{24}$ Syaikh al-Allamah Muhammad bin Abdurrahman ad-Dimasyqi, Fikib Empat Mą̧ab, terj. Abdullah Zaki Alkaf, (Bandung: Hasyimi, 2010), Cet. ke-13, h. 357.

${ }^{25}$ Muhammad Jawad Mughniyah, Fiqh Lima Maz̧̧ab, terj. Masykur A. B, (Jakarta:

Lentera, 2011), Cet. ke- 28, h. 375.

${ }^{26}$ Aziz Muhammad, Op. Cit. ,h. 211.

${ }^{27}$ al-Allamah Muhammad, Loc. Cit.

28 Aziz Muhammad, Loc. Cit.

${ }^{29}$ al-Allamah Muhammad, Op. Cit. , h. 357-358. 
4. pendapat ulama Syafi'iyah dan Imam Ahmad dalam satu periwayatan yang juga dikutip oleh Abdul Aziz Muhammad Azzam berpendapat bahwa, Masing-masing pendapat mempunyai dalil, saya tidak dapat mentarjih satu pendapat atas pendapat lain dalam hal ini. Menurut saya yang baik adalah apabila suami istri saling merelakan ukuran mut'ah, apa yang disepakati mereka berdua tentang ukuran mut'ah, suami melaksanakan, baik sedikit atau banyak. Jika mereka bertengkar tentang ukuran mut'ah, mereka lapor ke hakim untuk ditentukan ukurannya, demikian pendapat ulama Syafi'iyah dan Imam Ahmad dalam satu periwayatan yang juga dikutip oleh Aziz.

Ukuran mut'ah tidak diterangkan dalam syara', mut'ah berada di antara sesuatu yang memerlukan ijtihad maka wajib dikembalikan kepada hakim sebagaimana hal-hal lain yang memerlukan ijtihad.Ukuran mut'ab berbeda-beda sesuai dengan perbedaan zaman dan tempat.Mut'ah yang layak dan rasional pada suatu zaman terkadang tidak layak pada zaman lain. Demikian juga mut'ah yang layak di suatu tempat terkadang tidak layak ditempat lain.

Pendapat yang kuat adalah pendapat ulama Syafi'iyah, pendapat Abu Yusuf dari ulama Hanafiyah dan pendapat yang dijelaskan oleh Imam Ahmad, bahwa hakim ketika berijtihad tentang ukuran mut'ah hendaknya melihat kondisi suami, apakah tergolong mudah atau susah, kaya atau miskin.

\section{Mut'ah dalam Kompilasi Hukum Islam dan Undang-Undang Perkawinan}

Dalam sub bab ini akan diuraikan bagaimana mut'ah di dalam Kompilasi Hukum Islam (KHI) dan perundang-undangan perkawinan. Namun terlebih dahulu kita ketahui adalah mengenai putusnya perkawinan yang bagaimana sehingga mengakibatkan mut'ah.

Dalam Pasal 38 Undang-undang Nomor 1 tahun 1974 jo. Pasal 113 KHI disebutkan bahwa, perkawinan putus karena kematian, perceraian, atau atas keputusan pengadilan. ${ }^{30}$

Perkawinan dapat putus disebabkan perceraian sebagaimanayang dijelaskan pada pasal 114 yang membagi perceraian kepada dua bagian, perceraian yang disebabkan karena talak dan perceraian yang disebabkan oleh gugatan perceraian. $^{31}$

${ }^{30}$ Sulaikin Lubis, et all, Hukum Acara Perdata Peradilan Agama di Indonesia, (Jakarta:

Kencana Prenada Media Group, 2008), Cet. ke-3, h. 123.

${ }^{31}$ Amiur Nuruddin dan Azhari Akmal Tarigan, Hukum Perdata Islam di Indonesia, (Jakarta: Kencana Prenada Media Group, 2006), Cet. ke-3, h. 220. 
Mengenai masing-masing sebab perceraian, akibat yang ditimbulkannya berbeda bagi tiap-tiap pelakunya. Maka dari itu kita perlu memahami dulu apa yang dimaksud dengan cerai talak dan apa bedanya dengan cerai gugat. Cerai gugat merupakan perceraian yang berasal dari gugatan yang diajukan istri kepada Pengadilan Agama untuk menjatuhkan talak suaminya terhadap dirinya. Sedangkan cerai talak adalah cerai yang berasal dari permohonan suami ke Pengadilan Agama untuk menjatuhkan talak terhadap istrinya.

Pengertian cerai talak dapat kita pahami dari pasal 66 ayat (1) UU No. 7 tahun 1989, yang berbunyi:

Seorang suami yang beragama Islam yang akan menceraikan istrinya mengajukan permohonan kepada Pengadilan untuk. mengadakan sidang guna menyaksikan ikrar talak. ${ }^{32}$

Dari sana dapat kita ambil kesimpulan bahwa cerai talak adalah permohonan suami kepada pengadilan untuk menceraikan istrinya dengan menjatuhkan talak.Sedangkan pengertian cerai gugat dapat kita pahami dari pasal 73 ayat (1) UU No. 7 tahun 1989, yang berbunyi:

Gugatan perceraian diajukan oleh istri atau kuasanya kepada Pengadilan yang daerah hukum nya meliputi tempat kediaman penggugat, kecuali apabila penggugat dengan sengaja meninggalkan tempat kediaman bersama tampa izin tergugat. ${ }^{33}$

Dari pasal diatas dapat kita pahami bahwa cerai gugat adalah gugatan yang diajukan oleh istri kepada Pengadilan sesuai dengan daerah hukumnya untuk bercerai dengan suaminya.Perbedaannya dengan cerai talak adalah dari segi siapa yang mengajukan.Kalau cerai talak dari pihak suami tapi dalam bentuk permohonan sedangkan cerai gugat dari pihak istri tapi dalam bentuk gugatan.

Akibat cerai talak terdapat pada pasal 149 KHI yang bunyi pasalnya sebagai berikut:

Bilamana perkawinan putus karena talak, maka bekas suami wajib:

a) memberikan mut ah yang layak kepada bekas isterinya, baik. berupa uang atau benda, kecuali bekas isteri tersebut qobla al dukbul;

b) memberi nafkah, maskan dan kiswah kepada bekas isteri selama dalam iddah, kecuali bekas isteri telab dijatubi talak. ba'in atau nusyur dan dalam keadaan tidak. hamil;

c) melunasi mahar yang masib terbutang selurubnya, dan separub apabila qobla al dukbul;

d) memberikan biaya hadhanah untuk anak-anaknya yang belum mencapai umur 21 tabun. ${ }^{34}$

32Tim Redaksi Sinar Grafika, Amandemen Undang-Undang Peradilan Agama, Jakarta: Sinar Grafika, 2010), Cet. Pertama, h. 10.

${ }^{33}$ Ibid. ,h. 113. 
Ketentuan ini dimaksudkan agar bekas istri yang telah diceraikan suaminya jangan sampai menderita karena tidak mampu memenuhi kebutuhan hidupnya. Selanjutnya yang akan dibahas adalah mengenai point "a" yaitu mengenai mut'ah. Dalam KHI, diatur mengenai syarat mut'ah dalam pasal 158 yang berbunyi:

\section{Mut'ah wajib diberikan oleh bekas suami dengan syarat:}

a. belum ditetapkan mahar bagi istri ba'da ad-dukhul;

b. perceraian itu atas kehendak suami. ${ }^{35}$

Maksud dari point "a" adalah mut'ah itu wajib diberikan oleh bekas suami kepada bekas istri dengan syarat bahwa maharnya belum ditentukan setelah bercampur. Dan point "b" bermakna bahwa perceraian tersebut merupakan kehendak suami atau dengan kata lain merupakan cerai talak bukan cerai gugat dari pihak istri. Namun jika sudah terjadi pencampuran diantara suami istri maka mut'ah tidak wajib diberikan melainkan bersifat sunnah, hal tersebut berdasarkan pasal 159 KHI yang berbunyi sebagai berikut:

Mut'ah sunnah diberikan oleh bekas suami tanpa syarat tersebut pada pasal 158. ${ }^{36}$

Mengenai ukuran seberapa besar mut'ah yang harus diberikan, KHI membahas dalam pasal 160 yang berbunyi sebagai berikut:

Besarnya mut'ah disesuaikan dengan kepatutan dan kemampuan suami. ${ }^{37}$

Mengenai ukuran atau kadarmut'ah yang harus diberikan terhadap istri, berdasarkan pasal diatas adalah dengan kepatutan dan kemampuan suami. Yang dimaksud kepatutan adalah layak atau tidaknya jumlah tersebut untuk istri dilihat dari segi kemampuan ekonomi suami dan juga adat istiadat yang berlaku di lingkungan pihak-pihak yang berperkara tersebut. Walaupun pada dasarnya tetap bergantung pada kemampuan suami.

\section{Penentuan Kadar Mut'ah Wanita Karir dalam Pandangan Hukum Positif di Indonesia}

Dalam sub bab ini akan diuraikan bagaimana penentuan kadar mut'ah di dalam Kompilasi Hukum Islam (KHI). Hal yang mengakibatkan terjadinya mut'abadalah putusnya perkawinan.

${ }^{34}$ Ahmad Rofiq, Hukum Islam di Indonesia, (Jakarta: Rajawali Pers, 2003), Cet-6, h. 283.

35 Abdul Gani Abdullah, Pengantar Kompilasi Hukum Islam dalam Tata Hukum Indonesia, (Jakarta: Gema Insani press, 1994), h. 124.

${ }^{36}$ Ibid. ,h. 124.

${ }^{37}$ Tim Redaksi Pustaka Yustisia, Loc. Cit. 
Perkawinan dapat putus disebabkan perceraian sebagaimanayang dijelaskan pada pasal 114 yang membagi perceraian kepada dua bagian, Perceraian yang disebabkan karena talak dan perceraian yang disebabkan oleh gugatan perceraian. ${ }^{38}$ Mengenai masing-masing sebab perceraian, akibat yang ditimbulkannya berbeda bagi tiap-tiap pelakunya. Bisa dikarenakan cerai gugat ataupun cerai talak. Pengertian cerai talak dapat kita pahami dari pasal 66 ayat (1) UU No. 7 tahun 1989, yang berbunyi:

Seorang suami yang beragama Islam yang akan menceraikan istrinya mengajukan permohonan kepada Pengadilan untuk. mengadakan sidang guna menyaksikan ikrar talak. ${ }^{39}$

Dari sana dapat kita ambil kesimpulan bahwa cerai talak adalah permohonan suami kepada pengadilan untuk menceraikan istrinya dengan menjatuhkan talak.

Akibat cerai talak terdapat pada pasal $149 \mathrm{KHI}$ yang bunyi pasalnya sebagai berikut:

Bilamana perkawinan putus karena talak, maka bekas suami wajib:

a) memberikan mut ah yang layak kepada bekas isterinya, baik. berupa uang atau benda, kecuali bekas isteri tersebut qobla al dukbul;

b) memberi nafkah, maskan dan kiswah kepada bekas isteri selama dalam iddah, kecuali bekas isteri telah dijatubi talak ba'in atau nusyur dan dalam keadaan tidak hamil;

c) melunasi mahar yang masib terbutang selurubnya, dan separub apabila qobla al dukbul;

d) memberikan biaya hadhanah untuk anak-anaknya yang belum mencapai umur 21 tabun. ${ }^{40}$

Ketentuan ini dimaksudkan agar bekas istri yang telah diceraikan suaminya jangan sampai menderita karena tidak mampu memenuhi kebutuhan hidupnya. Dalam KHI, diatur mengenai syarat mut'ah dalam pasal 158 yang berbunyi:

Mut'ah wajib diberikan oleh bekas suami dengan syarat:

a. belum ditetapkan mahar bagi istri ba'da ad-dukhul;

b. perceraian itu atas kehendak suami. ${ }^{41}$

${ }^{38}$ Amiur Nuruddin dan Azhari Akmal Tarigan, Hukum Perdata Islam di Indonesia,

(Jakarta: Kencana Prenada Media Group, 2006), Cet. ke-3, h. 220.

${ }^{39}$ Tim Redaksi Sinar Grafika, Amandemen Undang-Undang Peradilan Agama, (Jakarta: Sinar Grafika, 2010), Cet. Pertama, h. 10.

${ }^{40}$ Ahmad Rofiq, Hukum Islam di Indonesia, (Jakarta: Rajawali Pers, 2003), Cet-6, h. 283.

${ }^{41}$ Abdul Gani Abdullah, Pengantar Kompilasi Hukum Islam dalam Tata Hukum Indonesia, (Jakarta: Gema Insani press, 1994), h. 124. 
Misalkan, jika seorang istri menuntut mut'ah dalam gugatan rekonvensi sebesar Rp 10.000.000,- terhadap suami yang berpenghasilan Rp 2.000.000,perbulan, maka berdasarkan pasal $160 \mathrm{KHI}$, mut'ab yang dikabulkan adalah sebesar kemampuan suami yaitu maksimal Rp 2.000.000,-. Bukan hanya jumlah penghasilan yang dilihat, tetapi juga kesanggupan yang benar-benar disanggupi oleh suami. Misalnya yang suami sanggupi sebesar adalah Rp 1.000.000,-, dikarenakan kebutuhan untuk dirinya mengandalkan dari gaji bulanan tersebut. Dan dinilai layak untuk disekitar adat istiadat lingkungan istri.

Tetapi kerap terjadi Pengadilan Agama memutuskan memberikan mut'ah kepada wanita yang ba'da dukbul. Walaupun dalam permohonan suami tidak mengajukan mut'ah dan dalam rekonvensi tidak ada diajukan gugatan mut'ah. Hal tersebut dikarenakan melihat kandungan situasi dan kondisi pihak terkait.Apakah layak atau tidak diberikan mut'ah, dan tetap berlandaskan dengan ketentuan pasal diatas.

Dalam penelitian ini penulis mengambil dua perkara cerai talak sebagai contoh analisa. Perkara cerai talak yang didalamnya terdapat putusan mut'ah dengan status istri memiliki pekerjaan atau wanita karir. Perkara yang pertama yaitu perkara 0556/Pdt.G/2013/PA.LLG. Perkara ini diajukan oleh suami yang bernama Andi (bukan nama sebenarnya) selanjutnya disebut sebagai pemohon terhadap istri yang bernama Een Kartika (bukan nama sebenarnya) selanjutnya disebut sebagai termohon Dalam perkara ini pemohon tidak mengajukan gugatan untuk memberikan mut'ah terhadap istrinya. Pemohon hanya mengajukan permohonan untuk mengucapkan ikrar talak terhadap termohon. Yang menjadi alasan pemohon mengajukan permohonan cerai talak secara garis besar adalah dikarenakan masalah ekonomi dan merasa kurang dilayani termohon. Masalah ekonomi tersebut dipicu oleh kesenjangan penghasilan antara pemohon dan termohon. Pemohon bekerja sebagai karyawan di Bank Swasta sedangkan termohon sebagai pegawai negeri sipil (PNS) di salah satu instansi daerah. Menurut pemohon, termohon sering menggunakan alasan pekerjaan tersebut untuk tidak melayaninya. Padahal orang lain yang bekerja sebagai PNS tetap masih bisa melayani suaminya.

Menanggapi alasan termohon dalam permohonan konvensi (gugatan awal), maka pemohon menolak dengan tegas semua alasan tersebut, dan mengajukan gugatan rekonvensi. Gugatan rekonvensi adalah gugatan yang diajukan tergugat sebagai gugatan balasan terhadap gugatan yang diajukan penggugat kepadanya. ${ }^{42}$ Yang dalam hal ini berarti termohon mengajukan

${ }^{42}$ M. Yahya Harahap, Hukum Acara Perdata, (Jakarta: Sinar Grafika, 2012), Cetakan ke12, h. 468. 
gugatan balasan kepada pemohon. Yang selanjutnya termohon disebut penggugat rekonvensi dan pemohon sebagai tergugat rekonvensi.

Adapun isi gugatan mut'ah termohon adalah sebagai berikut:

"Menghukum tergugat rekonvensi membayar nafkah mut'ah sebesar Rp 10.000.000,(sepuluh juta rupiab)"*3

Dalam tahap persidangan pemohon menyatakan tidak sanggup memberikan mut'ah sebesari Rp 10.000.000,- kepada termohon. Pemohon hanya sanggup memberikan sebesar Rp 5.000.000,- kepada termohon, dan didalam jumlah tersebut juga sekaligus membayar uang nafkah selama masa iddah. Iddah merupakan masa yang harus ditunggu oleh seorang perempuan yang telah bercerai dari suaminya supaya dapat kawin lagi untuk mengetahui bersih rahimnya atau melaksanakan perintah Allah. ${ }^{44}$

Mengenai tuntutan uang mut'ah tersebut, para majelis hakim dalam perkara ini mempertimbangkan beberapa hal untuk memutuskan berapa besar mut'ah yang harus diberikan. Yaitu yang pertama, pemohon benar terbukti sebagai karyawan swasta Bank Swasta dengan bukti slip gaji berpenghasilan Rp 2.500.00,- perbulan. Kedua, pemohon merasa tidak sanggup membayar tuntutan mut'ab termohon yang berjumlah Rp 10.000.000,- dengan alasan gaji diatas, jumlah uang mut'ah yang pemohon sanggupi adalah Rp 2.500.000,-.

Ketiga, berdasarkan pasal 149 Kompilasi Hukum Islam maka bekas suami wajib memberikan mut'ah yang layak kepada bekas istrinya, baik berupa uang atau benda, kecuali bekas istri tersebut qobla ad-dubkeul.......",45

Keempat, karena mut'ah ini hanya diberikan satu kali saja dan itu merupakan tanda penghibur atau kenang-kenangan bagi isteri yang ditalak oleh suami, dan sudah sangat wajar jika tergugat rekonpensi memberikan hal tersebut mengingat perkawinan keduanya sudah berjalan lebih dari 5 (lima) tahun lamanya

Dari beberapa hal yang dipertimbangkan diatas maka majelis hakim memutuskan bahwa kesanggupan pemohon untuk membayar uang mut'ah sebesar $\mathrm{Rp}$ 2.500.000,- dinilai majelis hakim kurang pantas dan kurang layak. Maka dari itu majelis hakim menetapkan yang layak dan pantas untuk mut'ah tersebut adalah $\mathrm{Rp}$ 4.000.000,- dan menghukum tergugat rekonvensi untuk membayarkannya kepada penggugat rekonvensi.

\footnotetext{
${ }^{43}$ Salinan putusan perkara nomor 0556/Pdt.G/2013/PA.LLG, h. 8.

${ }^{44}$ Amir Syarifuddin, Hukum Perkawinan Islam di Indonesia, (Jakarta: Prenada Media, 2007), Cet. kedua, h. 304.

${ }^{45}$ Tim Redaksi Sinar Grafika, Op. cit, h. 263.
} 
Perkara yang kedua yaitu perkara nomor 0241/Pdt.G/2013/PA.LLG. Perkara ini diajukan oleh suami yang bernama Rebo Hasani bin Junaidi selanjutnya disebut sebagai pemohon terhadap istri yang bernama Sunarti binti Narno Syang selanjutnya disebut sebagai termohon. Selama pernikahan yang sudah dibina selama sekitar setahun, anatra pemohon dan termohon dikaruniai satu orang anak perempuan. Dalam perkara ini pemohon tidak mengajukan gugatan untuk memberikan mut'ah terhadap istrinya. Sama dengan perkara yang pertama pemohon hanya mengajukan permohonan untuk mengucapkan ikrar talak terhadap termohon.

Yang menjadi alasan pemohon mengajukan permohonan perceraian adalah sebagai berikut:

1. Karena Termohon sebagai istri susah diatur, selalu membantah apa yang dikatakan Pemohon dan melawan terhadap Pemohon sebagai suami;

2. Termohon tidak mau diajak hidup mandiri pindah dari rumah orangtuanya;

3. Sekarang antara pemohon dengan termohon telah berpisah tempat tinggal selama 7 bulan (dari bulan Agustus 2012 hingga sekarang) karena Pemohon telah pulang kerumah orangtua Pemohon sendiri, sebab tidak tahan lagi tinggal dengan termohon. ${ }^{46}$

Menanggapi alasan termohon, maka pemohon menolak dengan tegas semua alasan tersebut.Dan mengajukan gugatan rekonvensi pada saat sidang agenda jawaban termohon. Yang dalam hal ini berarti termohon mengajukan gugatan balasan kepada pemohon. Yang selanjutnya termohon disebut penggugat rekonvensi dan pemohon sebagai tergugat rekonvensi.

Dalam rekonvensi tersebut, termohon menolak semua alasan yang diajukan pemohon namun termohon bersedia diceraikan oleh pemohon. Mengenai tuntutan, penggugat rekonvensi hanya menuntut kepada tergugat rekonvensi agar membayar nafkah anak seluruhnya berjumlah Rp 10.000.000,(sepuluh juta rupiah) dan tidak ada tuntutan mut'ab didalamnya.

Mengenai rekonvensi di atas majelis hakim menimbang landasan hukum tertulis sehingga pada putusan akhir perkara ini terdapat putusan uang mut'ah, yaituakibat putusnya perkawinan akibat talak berdasarkan pasal 149 huruf (a dan b) Kompilasi Hukum Islam, bekas suami wajib memberikan mut'ah yang layak baik berupa uang atau benda, dan wajib memberikan nafkah, maskan dan kiswah kepada bekas istri selama dalam iddah. ${ }^{47}$

\footnotetext{
${ }^{46}$ Salinan putusan perkara nomor 0241/Pdt.G/2013/PA.LLG, h. 2.

47 Ahmad Rofiq, Op. Cit. , h. 283.
} 
Selain landasan hukum diatas, majelis hakim juga menggunakan hak exofficio nya untuk menetapkan besarnya jumlah mut'ah dan nafkah iddah yang harus dibayar oleh pemohon kepada termohon sebagaimana yang akan ditetapkan dalam amar putusan ini. Hal itu disebabkan karena termohon tidak hadir lagi pada sidang-sidang selanjutnya.Hak ex-officio adalah hak yang dimiliki seorang hakim untuk menyelamatkan hak-hak tertentu dari pihak berpekara walaupun hal tersebut tidak disebutkan dalam petitum (tuntutan).Majelis hakim menilai, walaupun pekerjaan termohon sebagai seorang petani dengan penghasilan yang tidak menentu, hal ini tidaklah menggugurkan kewajiban pemohon untuk membayar mut'ab dan nafkah iddah terhadap termohon.

Maka dari itu hakim menetapkan menghukum pemohon untuk membayar uang mut'ah kepada termohon sebesar Rp 2.000.000,- (dua juta rupiah), adapun amar putusannya sebagai berikut:

Dari dua perkara tersebut diatas, menurut majelis hakim yang memeriksa, yang dalam hal ini diwakilkan oleh Bapak Cik Basir sebagai hakim anggotanya mengatakan bahwa status istri sebagai wanita yang memilki pekerjaan sendiri atau wanita karir, menjadi pertimbangan sendiri dalam memutuskan kadar mut'ah yang harus diberikan suami kepada bekas istri karena cerai talak. ${ }^{48}$

Hal tersebut pertama berdasarkan Kompilasi Hukum Islam (KHI) pasal $149 \mathrm{KHI}$ pada point a yang berbicara mengenai bilamana perkawinan putus karena talak, maka bekas suami wajib memberikan mut'ah yang layak kepada bekas isterinya, baik berupa uang atau benda, kecuali bekas isteri tersebut qobla al dukhul. Ketentuan ini dimaksudkan agar bekas istri yang telah diceraikan suaminya jangan sampai menderita karena tidak mampu memenuhi kebutuhan hidupnya. Baqarah:

Dan yang terakhir adalah berdasarkan firman Allah ayat 241 surah al-

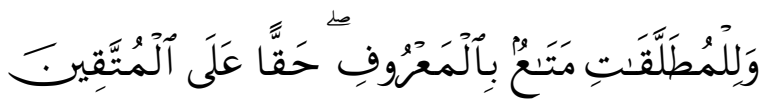

Kepada wanita-wanita yang diceraikan (bendaklah diberikan oleb suaminya) mut'ah menurut yang ma'ruf, sebagai suatu kewajiban bagi orang-orang yang bertakwa. ${ }^{49}$

Alquran tidak memberikan batasan tentang mut'ah ini, tetapi hanya menetapkan menurut yang ma'ruf. Batasan yang ma'ruf disinilah yang dianggap

${ }^{48}$ Wawancara dengan Bapak Cik Basir, SH., MHi selaku hakim di Pengadilan Agama Lubuklinggau kelas I.b pada tanggal 27 April 2014

${ }^{49}$ Hasbi Ash- Shiddieqy, Loc. Cit. 
layak oleh fitrah yang sehat, diakui oleh urf yang matang, serta diridhai oleh ahli ilmu dan agama.

Dengan mengambil dalil firman Allah surah al-Baqarah ayat 236 dan ayat 241, maka dapat disimpulkan beberapa hal sebagai berikut:

1. Kewajiban tidak hanya dikhususkan pada orang-orang yang berbuat baik dan takwa, tetapi juga kepada yang lain. Ketika mut'ab dikhususkan kepada mereka, menunjukkan bahwa mut'ah hukumnya tidak wajib,

2. Kekhususan mut'ah kepada orang-orang yang berbuat baik dan takwa didasarkan pada kebaikan (ihsan) dan anugerah, kebaikan tidak wajib. ${ }^{50}$

Dalil yang dijadikan dasar bagi pendapat kedua terjawab bahwa kewajiban terhadap orang yang berbuat baik dan takwa tidak menghilangkan kewajiban terhadap orang lain.

Ayat tersebut tidak meniadakan bahwa Alquran juga menunjukkan kepada manusia seluruhnya, baik takwa, orang yang berbuat baik, dan yang lainnya. Pendapat yang kuat berdasarkan penjabaran diatas adalah pendapat yang pertama karena kuat dalilnya dan selamat dari kontradiksi.

\section{Penutup}

Dari uraian diatas, maka ada tiga unsur kepatutan yang mesti diperhatikan dalam pemberian mut'ah. Pertama, kepatutan atau kepantasan berdasarkan kemampuan suami. Artinya, suami yang kaya tidak pantas memberikan mut'ah yang sama jumlahnya dengan suami yang termasuk golongan miskin, dan sebaliknya. Kedua, patut atau pantas bagi isteri. Artinya, isteri yang terbiasa dengan pola hidup cukup apalagi mewah dengan suami itu atau keluarganya sebelumnya bahkan jika dia bekerja dan memiliki penghasilan sendiri, tidak pantas kalau mendapat mut'ah yang jumlahnya sedikit, Oleh karena itu keadaan isteri lah yang jadi pedoman dalam penentuan mut'ab itu. Ketiga, patut atau pantas menurut adat yang berlaku di lingkungan tempat mereka hidup. Hal ini perlu mendapatkan perhatian, setidaknya, untuk menghindari terjadinya kesenjangan sosial antara isteri yang diberi mut'ah dengan orang-orang yang berada di sekitarnya dan kekhawatiran tidak mencukupinya biaya kehidupan anak dari hasil pernikahan tersebut. 


\section{Daftar Pustaka}

Abdullah, Abdul Gani.Pengantar Kompilasi Hukum Islam dalam Tata Hukum Indonesia, Jakarta: Gema Insani press, 1994.

Agama, Departemen. Al-Quran dan Terjemahnya.Bandung: Diponegoro. 2006.

Al-Allamah, Syaikh Muhammad bin Abdurrahman ad-Dimasyqi, Fikih Empat Mą̧hab, terj. Abdullah Zaki Alkaf, Bandung: Hasyimi, 2010, Cet. ke-13.

Al-Qaradhawi, Yusuf.Fatwa-Fatwa Kontemporer, terj. As'ad Yasin, Jakarta: Gema Insani, 2009, Cet. ke-6.

Ash- Shiddieqy, Hasbi. Tafsir Al-Bayan, Bandung: Al-Ma'arif, 1966, Jilid 1.

Aziz, Abdul Muhammad Azzam dan Abdul Wahhab Sayyed Hawwas, Figh Munakahat, Jakarta: Amzah, 2011, cet. ke-2.

Bungin, Burhan.Penelitian Kualitatif. Jakarta: Kencana, 2011, Cetakan ke lima.

Dzulfikar, Ahmad. Kamus Ekstra Lengkap Arab-Indonesia-Inggris, Jakarta: Mutiara Media, 2010, Cet. Pertama.

Hakim, Ihsanul Dkk. Pengantar Metodologi Penelitian, Curup: LP2 STAIN Curup.

Harahap, M. Yahya. Hukum Acara Perdata, Jakarta: Sinar Grafika, 2012, Cetakan ke dua belas.

Koto, Alaidin.Sejarah Peradilan Agama, Jakarta: Rajawali Pers, 2011, hal. 193.

Lubis, Sulaikin, et all, Hukum Acara Perdata Peradilan Agama di Indonesia, Jakarta: Kencana Prenada Media Group, 2008, Cet. ke-3.

Mughniyah,Muhammad Jawad. Fiqh Lima Mą̧ab, terj. Masykur A. B, Jakarta: Lentera, 2011, Cet. ke- 28.

Nuruddin, Amiur dan Azhari Akmal Tarigan.Hukum Perdata Islam di Indonesia, Jakarta: Kencana Prenada Media Group, 2006, Cet. ke-3.

Rofiq, Ahmad.Hukum Islam di Indonesia, Jakarta: Rajawali Pers, 2003, Cet-6.

Sabiq, Sayyid.Figh Sunnah, terj. Muhammad Thalib, Bandung: Al- Ma'arif, 2010, Jilid 8, Cet. ke-20.

, Fiqh Sunnah, terj. Muhammad Thalib, (Bandung: Al-Ma'arif, 2010),jilid 7, Cet. ke-20.

Saebeni, Beni Ahmad, Figh Munakahat 2, Bandung: Pustaka Setia, 2001, Cet. kedua. 
86 | Al-Istinbath: Jurnal Hukum Islam, Vol. 3, No. 1, 2018

Santoso, Gempur.Metodologi Penelitian. Jakarta: Prestasi Pustaka Publisher, 2012,Cetakan ke tiga.

Sonhadji dan Zaini Dahlan, Alquran dan Tafsirnya, Yogyakarta: Dana Bhakti Wakaf, 1990, Jilid 1.

Syarifuddin,Amir.Hukum Perkawinan Islam di Indonesia, Jakarta: Prenada Media, 2007, Cet. Kedua.

Tihami, H. M. A. dan Sohari Sahrani, Fikih Munakahat, Jakarta: Rajawali Pers, 2010, Cet. ke-2.

Tim Redaksi Pustaka Yustisia.Hukum Keluarga (Kumpulan Perundangan Tentang Kependudukan, Kompilasi Hukum Islam, Perkawinan, Perceraian, KDRT dan Anak), (Yogayakarta: Pustaka Yustisia. 2010), Cetakan pertama, hal. 234. 